\title{
KEPEMIMPINAN GEREJA: TINDAKAN (KIPRAH), BUKAN JABATAN! \\ Sumbangsih Pemikiran Bagi Pengembangan Kepemimpinan pada Gereja Masehi Injili di Halmahera
}

(GMIH)

\section{Ricardo Freedom Nanuru}

Staf Pengajar pada Fakultas Teologi Universitas Halmahera

e-mail: ricardonanuru632@gmail.com ricardo@uniera.ac.id

\section{"Pemimpin itu memimpin dengan contoh, Gukan dengan paksaan."}

(Sun Tzu)

\section{Pendahuluan}

Pemimpin itu dilihat dari kerjanya. Demikianlah satu kalimat bertanda petik degan huruf kapital yang ditulis mantan Ketua Gerakan Mahasiswa Kristen Indonesia (GMKI) Cabang Ambon, Bung Frans Julius Matwear di dinding facebook-nya tertanggal 17 Juni 2017. Tulisan itu ditautkan ke dinding facebook Pendeta Elifas Tomix Maspaitella, Sekretaris Umum Majelis Pekerja Harian (MPH) Sinode Gereja Protestan Maluku (GPM) untuk sekedar mengingatkan peristiwa masa lampau dimana kalimat itu "dinubuatkan" Bung Eltom (nama panggilannya) ketika membekali kadernya di Student Center GMKI Ambon, JI. Dr. G.A. Siwabessy Batu Gantung Ambon tahun 2003.

Berhasil tidaknya seorang pemimpin memang akan dilihat dari hasil kerjanya. Hasil itu tentu saja dipengaruhi oleh proses sejak awal menjadi pemimpin, proses manajemen kepemimpinan, dan evaluasinya, baik evaluasi proses maupun hasil kerjanya. Semua itu akan berujung pada penilaian berhasil atau tidaknya seorang pemimpin menjalankan tugas-tugas kepemimpinannya. Yang dikemukakan ini memang idealnya suatu proses kepemimpinan, siapapun pemimpinnya. Mungkin saja semboyan pemerintahan Presiden Jokowi: kerja, kerja, kerja, juga berasal dari landasan ideal ini dimana hasil kerja lewat penyelesaian program-program akan membuktikan kesuksesan suatu masa kepemimpinan.

Pembaca tentu bertanya, apa hubungan antara kedua paragraf di atas dengan tulisan ini? Bukankah tulisan ini didedikasikan pada Buku Penghargaan 10 Tahun Kepemimpinan Pendeta Anton Piga dalam menahkodai perahu Gereja Masehi Injili di Halmahera (GMIH)? Saya maklum dengan pertanyaan tersebut. Ada tiga alasan yang melatar-belakangi hal ini. Pertama, saya tidak menemukan kalimat pembuka yang tepat untuk menulis dalam waktu singkat selama beberapa hari memikirkan tentang tulisan ini. Kedua, saya kebetulan menengok akun facebook dan menemukan tulisan pada paragraf pertama. Alasan kedua memacu ingatan saya dan memunculkan alasan ketiga, yaitu saya mengenal cukup dekat Bung Eltom dan cukup tahu juga dengan proses yang dilewatinya hingga menjadi Sekretaris Umum MPH Sinode GPM. Saya mengingat betul kiprahnya di Senat Fakultas Teologi saat saya berkuliah. Kiprahnya di GMKI saat saya menjadi kadernya. Kiprahnya di Sekolah Tinggi Agama Kristen Protestan Negeri (STAKPN) Ambon saat menjadi dosen walau kemudian resign karena permintaan ayahnya yang akan meninggal (Ayah Bung Eltom menginginkannya menjadi Pendeta; sewaktu menjadi PNS Dosen di STAKPN, ia belum vikaris). Kiprahnya di Angkatan Muda Gereja Protestan Maluku (AM GPM), dimana ia pernah menjadi Ketua Umum OKP terbesar di Maluku ini. Dan sekarang, kiprahnya di kantor sinode GPM itu. Saya menjadi tertegun memikirkan kader-kader yang dihasilkannya dalam rentang kiprah kepemimpinan yang telah dilewatinya. Dalam tulisan ini, saya mau menyatakan bahwa Bung Eltom cukup sukses membuat kami, termasuk saya menjadi "orang" yang melayani dengan gigih. Pemimpin harusnya demikian: menanamkan prinsip pelayanan tanpa pamrih dan mengkaderkan pemimpin selanjutnya. Sampai di sini, saya mengingat Nabi Elia yang mengkaderkan Elisa; saya juga teringat Yesus yang mengkaderkan Simon Petrus dan murid lainnya. 
Bagi pembaca yang berasal dari $\mathrm{GMIH}$, tentu saja saya tidak menafikkan para pemimpin yang hadir silih berganti dalam gereja kita. Selama 12-an tahun bergereja di GMIH, saya merasa tidak memiliki cukup alasan untuk membandingkan pemimpin-pemimpin gereja kita dengan yang lainnya. Titik fokus saya hanyalah menghadirkan ideal-ideal pola kepemimpinan dan tantangan-tantangan yang akan dan harus dihadapi oleh para pekerja gereja serta memimpin umat melewatinya. Pola kepemimpinan gereja seperti apa yang harus diperjuangkan terus-menerus guna kebaikan umat, itulah yang harus dikembangkan oleh para pemimpin gereja. Berangkat dari keyakinan bahwa pola kepemimpinan gereja itu harus terus diperjuangkan demi kemajuan dan kesejahteraan umat, membuat tulisan ini dihadirkan bagi pembaca, terkhusus bagi pembaca di Gereja Masehi Injili di Halmahera (GMIH).

\section{Kepemimpinan: Apakah Itu?}

Mengamati rentang sejarah, dapat dikatakan bahwa kualitas kepemimpinan merupakan faktor penentu dalam keberhasilan suatu organisasi, baik dalam dunia usaha maupun dalam dunia pendidikan, pemerintahan, politik, kesehatan, dan agama, khsusnya agama Kristen. Organisasi apa pun di dunia ini pasti pernah mengalami kegagalan. Salah satu penyebabnya adalah faktor kepemimpinan yang kurang memadai (Djadi, 2009). Berikut dikemukakan beberapa defenisi kepemimpinan yang kait -mengait dengan tulisan ini.

Kepemimpinan adalah proses mempengaruhi atau memberi contoh oleh pemimpin kepada pengikutnya dalam upaya mencapai tujuan organisasi. Sangat jelas dinyatakan bahwa seseorang disebut pemimpin kalau dia dapat mempengaruhi atau memberi contoh kepada pengikutnya agar dapat mencapai suatu tujuan, terlepas dari apakah tujuannya baik atau tidak baik (Muliana, 2013). Dapat dikatakan bahwa kepemimpinan adalah seni memimpin yang memerlukan proses yang berisi pengaruh dan mempengaruhi guna mencapai tujuan organisasi. Proses itu tentu saja berjalan melalui berbagai cara yang tidak terlepas dari administrasi dan manajemen berorganisasi.

Kepemimpinan (leadership) adalah proses pengaruh-mempengaruhi antar pribadi atau antar orang dalam suatu situasi tertentu, melalui aktivitas komunikasi yang terarah untuk mencapai suatu tujuan atau tujuan-tujuan terntentu. Dalam kepemimpinan selalu terdapat unsur pemimpin (influencer), yakni yang mempengaruhi tingkah laku pengikutnya (influencee) atau para pengikutnya dalam suatu situasi (Djadi, 2009).

Pemimpin yang efektif adalah orang yang menciptakan visi inspiratif masa depan. Pemimpin itu mampu memotivasi dan mengilhami orang untuk terlibat dalam visi itu, mengatur penyampaian visi, menjadi pelatih dan membangun tim sehingga lebih efektif dalam mencapai visi. Kepemimpinan menyatukan keterampilan yang dibutuhkan untuk melakukan hal-hal ini. Seorang pemimpin melangkah di saat krisis, dan mampu berpikir dan bertindak kreatif dalam situasi sulit. Tidak seperti manajemen, kepemimpinan tidak bisa diajarkan, meski bisa dipelajari dan ditingkatkan melalui pembinaan atau pendampingan.

Kepemimpinan adalah bagian dari administrasi dalam arti luas. Sebuah organisasi digerakkan oleh administrasi. Administrasi dalam suaru organisasi dapat berjalan dengan baik apabila digerakkan oleh manajemen. Manajemen dapat berjalan dengan baik kalau ada kepemimpinan yang baik dan efektif. Kepemimpinan dapat berjalan lancar dan dapat mencapai tujuan organisasi apabila ada pengambilan keputusan-keputusan yang tepat. Pengambilan keputusan-keputusan yang tepat sangat ditentukan oleh kualitas moral dan karakter dari si pengambil keputusan. Karena itu dapat disimpulkan bahwa inti dari administrasi adalah manajemen, inti dari manajemen adalah kepemimpinan, inti kepemimpinan adalah pengambilan keputusan, dan inti pengambilan keputusan 
adalah moral dan karakter. Moral, karakter, spiritual dan iman seorang pemimpin sangat menentukan kualitas keputusan yang diambilnya. Kualitas keputusan itulah yang akan menentukan apakah seorang pemimpin itu dikategorikan baik, biasa saja, atau dikategorikan buruk. namun perlu juga diperhatikan bahwa kualitas keputusan yang baik hendaknya diikuti dengan implementasi yang baik. Pemimpin yang baik akan mengawal pelaksanaan keputusannya sampai kepada tercapainya tujuan yang telah ditetapkan (Jason, 2009).

Seorang pemimpin yang baik pasti menjalankan fungsi-fungsi manajemen dengan cermat. Fungifungsi manajemen yang harus dijalankan itu, menurut konsep George R. Terry, adalah perencanaan, pengorganisasian, penggerakkan, dan pengawasan. Menurur konsep Urwich, fungsi-fungsi dari manajemen itu meliputi: perencanaan, pengorganisasian, penetapan staf pelaksana, pangarahan dan pangawasan, pengkoordinasian, pelaporan, serta penyusunan dan penetapan anggaran. Kepemimpinan sebagai inti dari manajemen tidak dapat dipisahkan, bagaikan dua sisi dari satu mata uang. Kepemimpinan sebagai subyek dan manajemen sebagai sarana, sedangkan organisasi sebagai wadah kegiatan administrasi (Jason, 2009).

Prinsip dan fungsi kepemimpinan yang dikemukakan di atas berlaku secara universal pada semua organisasi, termasuk di dalamnya organisasi keagamaan seperti organisasi gereja. Dalam perkembangan global dewasa ini, proses kepemimpinan sedang mengalami suatu perubahan yang cukup mengejutkan. Dunia bisnis yang sering dipersepsi sekuler dan "kotor" mulai mengadopsi prinsip dan pola kepemimpinan dalam "dunia kitab suci". Kita dapat melihat berkembangnya berbagai bank syariah di Islam serta credit union di kalangan gereja. Hal ini tentu saja menarik karena dunia sekuler mulai melirik prinsip-prinsip alkitabiah, sementara di pihak gereja sendiri gereja malah mengaborsi prinsip dan pola tersebut. Inilah satu hal yang sedang terjadi dan belum disadari oleh para pemimpin gereja yeng telah memiliki dasar dalam kepemimpinannya, yaitu kepemimpinan Alkitabiah yang sesuai dengan ajaran Yesus (Ferry, 2013).

Pertanyaan utama yang dapat dihadirkan di sini adalah apakah pemimpin dilahirkan atau dibuat? Pertanyaan ini mempengaruhi gagasan kepemimpinan dalam gereja juga. Jika pemimpim sebenarnya tidak lahir, namun dibuat, maka pertanyaannya adalah proses, konteks, dan praktik apa yang memfasilitasi pengembangan kepemimpinan di gereja abad ke-21 sedemikian rupa dalam kerangka memberdayakan para pemimpin untuk memandang diri mereka sebagai bagian dari keseluruhan pelayanan dan tergantung dari keseluruhan itu juga? (Elkington, Meekins, Breen, \& Martin, 2015). Pertanyaan ini begitu penting mengingat konteks baru abad ke-21 yang mempengaruhi pengembangan kepemimpinan dalam gereja yang bersifat misional. Misi kepemimpinan seperti apa yang perlu dibahas, pemimpin seperti apakah yang diperlukn umat, serta tantangan apakah yang dihadapi dalam proses kepemimpinan, itulah yang akan diulas dalam bagian selanjutnya dalam tulisan ini.

\section{Kepemipinan Gereja: Kepemimpinan Gembala.}

Jika pembaca membuka mesin pencari Google (google.co.id) dan mencari dengan menggunakan kata kunci: "kepemimpinan gereja" maka pembaca akan diperhadapkan dengan model-model kepemimpinan gereja dari berbagai tinjauan sudut pandang. Beragam judul artikel muncul menghiasi laman google, di antaranya: Gereja dan kepemimpinan dalam jemaat; kepemimpinan gereja dan pelayanan; model-model kepemimpinan gereja; gereja membutuhkan seorang pemimpin yang melayani; manajemen kepemimpinan gereja; kepemimpinan dalam gereja mula-mula; kepemimpinan alkitabiah dalam gereja dan keluarga; dan masih ratusan ribu alternatif judul lainnya. Ternyata, bahasan seputar kepemimpinan gereja telah dengan sangat luar biasa dibahas. Hal ini terlihat dengan begitu banyaknya judul (498 ribu) yang muncul hanya dengan kata kunci dalam bahasa Indonesia tersebut. Ini belum termasuk pencarian dalam bahasa Inggris. Jika pembaca 
mencari dengan kata kunci: leadership of church, maka akan muncul 113 juta jawaban google dengan berbagai judul yang dapat memperkaya khasanah kepemimpinan gereja yang kita gumuli. Sangat luar biasa bukan? Ini belum termasuk pencarian dengan menggunakan bahasa-bahasa lain di dunia.

Saya menyebut apa yang dibahas pada paragraf di atas sebagai "kekayaan kepemimpinan gereja" yang akan terus diperbarui dengan ide-ide serta praktek-praktek kepemimpinan gaya baru. Tentu saja ada satu landasan ideal yang menurut keyakinan saya tidak akan ditinggakan para penggagas pola-pola kepemimpinan kristen di gereja yaitu Alkitab. Kepemimpinan gereja, menurut saya tentu saja tidak akan terlepas dengan pola kepemimpinan alkitabiah. Cobalah perhatikan tulisan-tulisan atau artikel-artikel yang jutaan jumlahnya itu, saya tak dapat menghitungnya, tetapi banyak sekali yang menggunakan dasar alkitabiah dalam pembahasannya. Itulah mengapa saya begitu yakin dengan landasan ideal kepemimpinan gereja yaitu Alkitab.

Ada banyak model kepemimpinan dalam Alkitab, antara lain sekolah para nabi, kepemimpinan hamba, hubungan guru-pelajar, pemuridan, coaching, mentoring, dan yang paling "ngetop" menurut beberapa ahli yaitu kepemimpinan model gembala yang didasarkan pada Mazmur 23: Tuhan, gembalaku yang baik. Mazmur ini dimulai dengan pernyataan meyakinkan: "Tuhan adalah gembalaku, takkan kekurangan aku." Mazmur ini menjadi salah satu nyanyian yang paling dikenal dan dihargai dalam literatur Perjanjian Lama yang pernah ditulis. Mazmur ini merupakan hasil refleksi Daud terhadap tugas Tuhan sebagai gembala-pemimpin bagi rakyatnya. Mazmur ini merupakan semacam daftar pelajaran tentang tugas kepemimpinan dan refleksi kritis tentang tugas kepemimpinan dari membimbing domba. Tuhan adalah gembalaku adalah gambaran kepedulian, keberanian, dan bimbingan (Resane, 2014).

Perjanjian Baru memiliki 16 referensi terkait gembala. Baiklah dikemukakan bererapa yang dapat menjadi referensi penting bagi kepemimpinan gereja. Para gembala berada di antara yang pertama untuk menerima pesan kelahiran Yesus dan mengunjungiNya (Luk 2: 8-20). Gembala dan domba digunakan untuk menggambarkan hubungan Kristus dengan pengikutNya yang menyebutnya sebagai Tuhan Yesus, dan bahwa gembala lebih besar dari domba (Ibr 13:20). Yesus mengemukakan pelajaran dalam perumpamaan penting bahwa diriNya sebagai gembala yang baik, yang tahu dombaNya, dan akan memberikan nyawaNya bagi mereka (Yoh 10: 7-18). Setelah kebangkitanNya, Yesus menugaskan Petrus untuk menggembalakan atau memberi makan domba-dombaNya (Yoh 21: 15-17). Dalam pidato perpisahannya kepada para penatua di Efesus, Paulus menggambarkan gereja dan para pemimpinnya sebagai kawanan dengan gembala (KPR 20:28) (Resane, 2014).

Gereja tentu tidak begitu saja digambarkan sebagai kawanan (domba) dan kepemimpinan (pemimpin) entah itu penatua, syamas, pastor (pendeta) digambarkan sebagai gembala. Tentu saja ada latar belakang kenyataan-kenyataan riil dan pola pikir yang dibangun berdasarkan pengalaman umat bergereja. Pada zaman Yesus tentu saja penggembalaan kawanan domba masih merupakan sesuatu yang penting, sehingga dipakai sebagai contoh. Dalam konteks ini, Yesus adalah "gembala yang baik" dan sering digunakan kualitas seorang gembala yang baik untuk mengajarkan berbagai pelajaran penting bagi domba-dombanya.

Apa saja pelajaran yang dapat dipetik dari gembala? mari kita pelajari peran dan fungsi gembala dalam Alkitab. Referensi Alkitab yang pertama untuk proses menggembalakan dapat dilihat pada Habel, putra Adam (Kej 4: 2). Penggembala adalah pekerjaan utama orang Israel di awal zaman patriarkal. Beberapa contoh dapat disebut, antara lain Abraham (Kej 12: 16); Rachel (Kej 29: 9); Yakub (Kej 30: 31-40) dan Musa (Kel 3: 1). Fungsi gembala secara luas adalah memimpin domba ke padang rumput dan air (kebutuhan makan minum) (Maz 23: 1). Melindungi dari hewan liar (keamanan) (1 Sam 17: 34-35). Menjaga kawanan di malam hari, apakah di tempat terbuka (Luk 2: 8) atau di padang rumput (Zef 2: 6) di mana mereka menghitung domba-domba ketika kembali 
memasuki areal perkemahan (Yer 33: 13). Para gembala mengurus dombanya dengan teliti bahkan membawa anak domba yang lemah di lengan mereka (Yes 40: 11) (Resane, 2014).

Di sisi lain, domba mewakili kekayaan karena mereka menyediakan makanan (susu); pakaian (wol dan kulit); dan tempat tinggal (kulit untuk tenda). Selanjutnya, domba memainkan peran utama dalam sistem korban Lewi. Mereka ditawarkan sebagai korban bakaran (Im 1: 10), korban penghapus dosa (Im 4: 32), korban rasa bersalah (Im 5: 15), dan korban keselamatan (Im 22: 21) (Resane, 2014). Demikianlah dalam Perjanjian Lama, kepemimpinan diibaratkan layaknya seorang gembala yang mengumpulkan anak-anak domba dalam pelukannya dan membawa mereka dekat dengan hatinya; ia lembut memimpin orang-orang muda dengan belas kasih agar terhindar dari predator yang selalu bersiap memangsa mereka. Gembala dan domba memiliki semacam keterikatan "simbiosis mutualisme" yang saling membutuhkan. Jadi tidak ada anggapan gembala lebih penting dari domba di antara keduanya.

Perumpamaan dari Perjanjian Baru tentang gembala dapat dilihat pada Injil Yohanes 10, khususnya ayat 14 dan 16:

"Akulah gembala yang baik dan Aku mengenal domba-domba-Ku dan domba-domba-Ku mengenal Aku... Ada lagi pada-Ku domba-domba lain, yang bukan dari kandang ini; dombadomba itu harus Kutuntun juga dan mereka akan mendengarkan suara-Ku dan mereka akan menjadi satu kawanan dengan satu gembala."

Tantangan bagi gembala di sini adalah bagaimana ia mengajar para domba untuk mematuhi perintahnya. Gembala yang baik akan merawat dan bertanggung jawab, bahkan memberi namanama yang akan direspon jika dipanggil. Tugas dan tanggung jawab besar gembala di sini adalah mempedulikan, berani membela, dan membimbing domba-dombanya. Pola kepemimpinan gembala ini dikombinasikan dengan baik oleh Lukas 22: 26 yang menyatakan bahwa yang menjadi pemimpin adalah mereka yang siap menjadi orang-orang yang melayani. Kepedulian pemimpin-gembala meliputi fungsi restorasi yang memerlukan aspek mencari, menemukan, dan membawa pulang. Ini semua ditemukan dan terekspos dalam Yohanes 10. Yesus, sebagai Gembala yang baik cemas untuk memulihkan atau menemukan domba yang hilang (Yoh 10: 11). Yesus meninggalkan 99 dan mencari 1 yang hilang. Gembala tidak menyerah sampai domba yang hilang ditemukan, dan la tidak memarahinya malahan menggendong dan mengobatinya. Kasih yang tulus bukan hanya tentang mengobati tetapi juga mendisiplinkan (Resane, 2014). Satu hal yang sering dilupakan pada peran mendisiplinkan adalah gembala yang baik akan mematahkan salah satu kaki domba keras kepala yang melawannya, dan akan menggendong serta mengobatinya sepanjang perjalanan. Pada saatnya, sang domba tersebut akan menjadi yang paling setia dan penurut dalam proses penggembalaan itu.

Keberanian merupakan salah satu hal penting lainnya dari kualitas kepemimpinan yang harus dimiiki pemimpin-gembala. Hal ini berkaitan dengan peran gembala dalam menghadapi situasi bahaya yang mengancam komunitas gembalaannya. Keberanian diperlukan pemimpin gereja yang bertindak sebagai gembala untuk menghadapi tuduhan-tuduhan dan serangan kawanan "predator". Pemimpin-gembala yang berani akan berdiri paling depan dan menjadi yang pertama bertindak menghadapi ancaman dengan penuh percaya diri. Para pemimpin gereja dengan demikian menempatkan kehidupan mereka pada resiko demi keselamatan domba-domba (umat). Mereka bukan gembala-gembala upahan yang cenderung meninggalkan para domba ketika ada serangan yang akan menghancurkan kawanan. Penegasan penting seputar Kepemimpinan gereja di sini adalah menjadi pemimpin itu bukan hanya untuk "martabat" tetapi juga untuk "kegunaan". Inilah fungsi fundamental hodegos (pemimpin atau pemandu) (Resane, 2014).

Pemimpin juga tidaklah lepas dari kritikan. Hal ini terlihat ketika Yesus menggunakan hodegos sebagai kiasan di Matius 23: 16 dan 24 di mana la mengkritik ahli-ahli Taurat dan orang-orang Farisi dalam menjalankan kepemimpinan mereka. Yesus mengibaratkan kepemimpinan mereka sebagai 
kepemimpinan yang buta terhadap situasi kehidupan umat di sekitarnya. Yesus bahkan mengajarkan para murid untuk melakukan dan menuruti perkataan para ahli Taurat dan orang-orang Farisi tetapi melarang melakukan apa yang mereka lakukan (Mat 23: 3), karena perkataan mereka benar tetapi perbuatan yang dilakukan tidak sejalan dengan perkataan yang diucapkan dalam ajaran-ajaran mereka.

Kepemimpinan gereja yang di dalamnya menganut filosofi pemimpin-gembala harus memiliki keberanian untuk berpartisipasi aktif dalam perubahan lingkungan (courage to participate in changing environment). Gembala-gembala mestinya proaktif untuk berubah. Tujuan utama perubahan adalah meningkatkan skill dalam pengawasan, pembimbingan, dan pengarah dalam konteks perubahan lingkungan yang mengancam para domba.

'leaders in God's mission must lead in a rapidly changing world - in social, cultural, economic, political and religious environments at local, national, and global levels'. The shepherd-leader participates in eschatological journey with the sheep, as he is also a human being still under construction (Franklin K, 2009).

Gembala dan domba (pemimpin dan umat) sepatutnya menjalani hidup bersama demi kepentingan bersama pula. Gembala yang baik, yang mengacu pada Yesus, peduli pada domba-dombanya baik individu maupun kawanan. Fungsi utama pemimpin gembala: merawat, membimbing dan berani mengambil resiko dengan cara yang efektif hendaknya dipraktekan dengan penuh tanggung jawab. Gembala yang baik memberikan nyawanya bagi domba-dombanya, bukan bersembunyi di balik kawanan jika "predator" menyerang. Itulah kepemimpinan gereja, kepemimpinan yang merawat, membimbing dan berani menantang perubahan zaman.

\section{Tantangan Kepemimpinan Gereja Masa Kini}

Gereja bertumbuh dan berkembang di dunia. Pernyataan singkat ini mengindikasikan bahwa gereja harus ikut berkembang seiring dengan perkembangan dunia dengan berbagai teknologi informasi mutakhir yang turut mengubah manusia-manusia yang mendiaminya. Perubahan mana membutuhkan kepekaan dan loyalitas kepemimpinan gereja dalam menyikapinya, termasuk menyikapi dampak negatif perkembangan tersebut. Berikut dikemukakan secara singkat beberapa tantangan riil dalam proses kepemimpinan gereja, di mana pemimpin atau para pemimpin perlu mengantisipasinya ke depan.

\section{A. Pemimpin Gereja: Pelayan bukan Tuan!}

Tantangan pertama datang dari dalam diri kepemimpinan gereja. Tantangannya berupa kemampuan (skill), sikap mental, dan motivasi kepemimpinan. Belakangan ini, disadari atau tidak, aroma "tuan besar" dalam pelayanan gereja cenderung menguat seiring dengan menguatnya aroma "tuan besar" dalam kepemimpinan sekuler. Pemimpin di gereja seakan-akan menjadi kans untuk berkuasa. Padahal, hakikat kepemimpinan gereja adalah pelayanan. Pemimpin gereja adalah pelayan.

“.... Barang siapa ingin menjadi besar di antara kamu, hendaklah ia menjadi pelayanmu, dan barang siapa ingin menjadi terkemuka di antara kamu, hendaklah ia menjadi hambamu;" (Mat 20: 26 dan 27).

Barangsiapa yang ingin menjadi pemimpin haruslah menjadi pelayan dan barangsiapa ingin menjadi besar di antara kamu hendaklah ia menjadi pelayanmu. Dari kedua pernyataan ini jelas bahwa yang ingin menjadi pemimpin atau menjadi yang terbesar ia harus terlebih dahulu menjadi seorang pelayan bagi yang lainnya. Kata "harus" dalam Alkitab Bahasa Indonesia Sehari-hari dan "hendaklah" dalam Alkitab Terjemahan Baru memberi satu perintah atau merupakan suatu kewajiban yang harus 
dilakukan bagi setiap orang yang ingin menjadi pemimpin. Hal itu sangat jelas ditegaskan oleh Yesus dalam ayat ini kepada murid-murid-Nya pada waktu itu. Menjadi pelayan merupakan hal yang wajib atau harus dilakukan bagi mereka yang ingin menjadi pemimpin dan hal itu harus selalu tampak dalam setiap pribadi yang ingin menjadi pemimpin (Ferry, 2013).

Jika paradigma kepemimpinan gereja adalah pemimpin yang melayani dan bukan dilayani maka visi Yesus yag tertuang dalam Matius 20: 26 dan 27 di atas telah dijalankan dengan benar. Tantangan permintaan ibu Yakobus dan Yohanes dalam kaitan dengan pemimpin yang memerintah dalam Matius 20: 20-28 sepatutnya dipahami dalam konteks yang sedang terjadi akhir-akhir ini dimana suksesi kepemimpinan baik di kalangan gereja maupun sekuler sedang terjadi. Kemampuan manajemen kepemimpinan yang ditunjang dengan sikap mental (karakter) dan motivasi memimpin sangat diperlukan demi menunjang proses kepemimpinan dalam gereja. Pembaca tentu saja tidak perlu diajari panjang lebar tentang hal ini, apalagi pembaca yang pernah mengecap pendidikan di perguruan tinggi.

\section{B. Pemimpin Gereja: Jangan Pura-Pura Buta!}

Judul di atas sengaja dikemukakan penulis bagi pembaca dengan harapan agar kita peka terhadap beberapa persoalan penting yang mengemuka belakangan ini. Beberapa orang mungkin akan gusar membaca judul ini, namun beberapa lainnya mungkin akan tersadar bahwa memang inilah masalah dan tantangan kita bergereja di GMIH. Beberapa permasalahan krusial yang menjadi tantangan gereja secara umum maupun $\mathrm{GMIH}$ secara khusus, dapat disebutkan antara lain persoalan kemiskinan, perkembangan HIV AIDS, Globalisasi dan perkembangan teknologi informasi, serta ekploitasi dan kerusakan lingkungan yang terus didengungkan. Hal ini tentu saja tidak menafikkan persoalan-persoalan lainnya yang juga sama-sama pentingnya. Baiklah kita mengulas secara singkat beberapa hal yang disebutkan di atas.

\section{1) Kemiskinan}

Persoalan kemiskinan merupakan persoalan klasik yang dihadapi gereja, yang pada hakekatnya bertumpu pada upaya memberdayakan masyarakat sehingga mampu bertahan (survive) dalam terjangan krisis ekonomi baik nasional maupun global dan juga meningkatkan daya tahan masyarakat untuk mencapai taraf kesejahteraan minimal, yakni terpenuhinya kebutuhan-kebutuhan pokok pada aras domestik (rumah tangga): sandang, pangan, rumah, pendidikan, pekerjaan mandiri, secara berkelanjutan (Nanuru, 2011).

Dengan demikian, persoalan kemiskinan bagi gereja tidak dipandang dalam suatu perspektif problem individual atau domestik belaka, melainkan sebagai persoalan struktural yang perlu dicermati, dianalisis, dan dicari solusinya secara strategis, praktis, dan komprehensif agar terjadi transformasi sosial yang ditopang oleh transformasi kebijakan-kebijakan pembangunan ekonomi oleh negara. Angka kemiskinan selalu memperlihatkan adanya sistem-sistem regulasi pembangunan yang masih terbatas atau kurang tepat sasar di satu sisi, di sisi lain memperlihatkan juga kemampuan masyarakat untuk memberdayakan dirinya yang masih lemah. Ini adalah bagian dari tanggungjawab gereja untuk menjadi 'gereja bersama orang miskin' (church with the poor) (Nanuru, 2011).

Masyarakat Kristen di Maluku Utara khususnya yang berada di bawah naungan Gereja Masehi Injili di Halmahera (GMIH), dapat dikatakan menyumbang angka kemiskinan yang cukup besar. Data riil mengenai hal ini memang tidak dapat dikemukakan karena belum diteliti secara detil tetapi berdasarkan penelitian penulis bersama salah satu rekan pendeta GMIH pada beberapa jemaat di Wilayah Pelayanan GMIH Morotai Selatan, terlihat jelas bahwa sebagian besar jemaat Kristen hidup di bawah garis kemiskinan berdasarkan standar yang dikeluarkan oleh pemerintah. Anehnya, masyarakat Kristen ini tidak menyadari bahwa mereka termasuk golongan masyarakat miskin seperti ditetapkan oleh pemerintah. Hal ini mengindikasikan bahwa pemahaman mereka tentang 
kemiskinan masih sangat minim dan butuh pencerahan. Pertanyaan pentingnya adalah, tugas dan tanggung jawab pencerahan itu harus diembankan di pundak siapa? Bukankah kekristenan sudah berakar cukup lama di negeri ini? Kawasan terluar, "bibir pasifik" yang harusnya mendapat perhatian serius dari berbagai pihak, termasuk gereja (Djurubasa \& Nanuru, 2015). ${ }^{1}$

Pemimpin gereja dengan demikian memiliki peran penting dalam menuntun "domba-domba" gembalaannya ke padang rumput hijau dan air yang tenang. Sebagai pemimpin-gembala, tugas merawat, melindungi dan mengarahkan umat ke arah kesejahteraan yang dikiaskan sebagai padang rumput hijau dan air tenang merupakan hal wajib yang mestinya disadari dan dilaksanakan dengan sepenuh hati. Sekali lagi, saya tidak perlu mengajari pembaca terkait langkah-langkah teknis penggembalaan ini, apalagi pembaca di GMIH yang pernah mengenyam pendidikan di perguruan tinggi.

\section{2) HIV AIDS}

Jumlah pengidap human immunodeficiency virus (HIV) yang dapat mengakibatkan penyakit AIDS di Maluku Utara kian mengkhawatirkan. Data yang diperoleh Tempo, pada 2004-2015, kasus HIV di Maluku Utara mencapai 627 kasus yang terdiri atas 203 kasus HIV dan 424 kasus AIDS. Dari jumlah tersebut, Kota Ternate menjadi daerah yang memiliki kasus HIV/AIDS tertinggi, yaitu mencapai 243 kasus, disusul Kabupaten Halmahera Utara dengan 229 kasus, Halmahera Barat 40 kasus, dan Halmahera Timur 33 kasus. Adapun HIV/AIDS di Kota Tidore Kepulauan mencapai 31 kasus, Halmahera Selatan 19 kasus, Kepulauan Sula 18 kasus, Pulau Morotai 10 kasus, dan Halmahera Tengah 4 kasus. Jika berdasarkan persentase kumulatif usia, pengidap HIV AIDS tertinggi di Maluku Utara lebih banyak terjadi pada usia produktif 30-39 tahun yang mencapai 38,7 persen dan usia 20-29 tahun sebanyak 38,4 persen (Nurgianto, 2016). Tentu saja jumlah kasus HIV AIDS akan terus meningkat dari tahun ke tahun seiring berjalannya waktu.

Jika kita menggunakan teori gunung es, maka tentu saja berita Tempo di atas hanyalah sedikit dari saudara-saudara kita yang telah mengalami masalah ini. Ada badan gunung di dalam lautan yang belum kelihatan. Sebagai gereja, kita dituntut untuk terlibat secara aktif dalam proses mulai dari pencegahan sampai penanganan secara langsung lewat program-program lembaga gereja. Penanggulangan ini tidaklah sebatas jargon tanpa langkah yang konkrit. Intervensi lewat programprogram kerja dari aras sinodal sampai jemaat diperlukan, yang tentu saja memerlukan bantuan semua pihak terkait termasuk sumber daya manusia gereja yang tersebar di berbagai intansi pemerintah maupun swasta. Lagi-lagi, saya tidak perlu menggurui pembaca dalam hal ini.

Inilah tantangan kedua bagi kepemimpinan gereja, di mana penanganan masalah HIV AIDS lewat program-program unggulan gereja perlu dihadirkan. Rencana-rencana strategis perlu digagas berdasarkan permasalahan riil umat yang terjadi. Studi-studi atau hasil-hasil studi lembaga-lembaga binaan gereja maupun lembaga swadaya masyarakat dan lembaga pemerintah perlu diintip dan digunakan dalam meramu berbagai program yang berguna bagi kemajuan dan proteksi umat sebagai domba yang wajib dituntun ke padang rumput hijau dan air yang tenang. Bukankah kesejahteraan yang dikiaskan pada Mazmur 23 itu adalah tanggung jawab kepemimpinan gereja? Sampai sejauh mana pemimpin-gembala melaksanakannya?

\section{3) Globalisasi dan Perkembangan Teknologi Informasi}

Globalisasi memainkan peranan penting sebagai problem dalam pelayanan gereja. Berkembangnya berbagai teknologi dan sumber-sumber informasi dan komunikasi membuat dunia serasa ada di genggaman tangan. Seiring dengan perkembangan ini, berbagai tindakan kriminalitas terjadi dan

\footnotetext{
${ }^{1}$ Laporan lengkap penelitian ini dapat dibaca pada arsip penelitian yang tersimpan di LPPM Universitas Halmahera.
} 
merebak dalam lingkup global, dengan aktor-aktor kriminal lintas benua. Korban-korban kriminalitas tidak lagi hanya pada cakupan geografis suatu negara, tetapi meluas hingga ke taraf internasional. Internet telah pula menjadi media subur bagi merebaknya kriminalitas virtual yang sulit dilacak oleh aparat hukum secara konvensional. Terorisme dalam arti yang lebih luas sebenarnya merembes dalam struktur kesadaran sosial masyarakat melalui jejaring virtual (internet), yang makin memperluas motivasi-motivasi dan aksi-aksi kekerasan ke seluruh dunia tanpa mampu dibendung (Nanuru, 2011).

Selain itu, globalisasi ekonomi turut memberi andil terhadap pemiskinan yang secara sistematis dilakukan oleh pemilik-pemilik kapital yang menggunakan kekuatan ekonomi untuk menekan kekuasaan, sehingga berakibat pada pemiskinan masyarakat yang terkadang tidak menyadari bahwa dirinya telah dirasionalisasi sedemikian rupa agar menerima keadaan hidupnya yang sekarang. Pada konteks seperti ini, gereja dipertanyakan posisi dan fungsinya dalam memperjuangkan keadilan bagi masyarakat (Nanuru, 2011).

Pembaca tentu sepakat bahwa dunia dalam tataran global sekarang dapat digenggam dalam tangan setiap orang, baik dewasa maupun anak-anak. Hal ini tentu memiliki dampak, baik positif maupun negatif. Marilah para pemimpin-gembala, kita memikirkan solusi terhadap tantangan global ini. Mengambil contoh Gereja Protestan Maluku (GPM) dengan Media Center-nya yang belakangan ini mulai berkiprah dengan berbagai program berbasis teknologi informasi. Berbagai kegiatan pelatihan dari tingkat sinodal sampai jemaat dilakukan. Baik jemaat dewasa maupun anak-remaja dilatih demi memanfaatkan teknologi informasi yang semakin canggih. Terakhir dalam pantauan penulis, kegiatan pelatihan "Ngeblog Menggunakan Smartphone" diberikan bagi anak-remaja sekolah minggu. Pembaca dapat menelusuri kegiatan-kegiatan lainnya dari GPM lewat website http://sinodegpm.org/. Kegiatan-kegiatan ini seharusnya membuat anak-anak penerus masa depan gereja mampu bersikap terbuka dan cinta akan teknologi dan berpikiran positif menghadapinya.

Belajar menghadapi tantangan dengan meniru hal baik dari orang lain itu wajar dan penting. Setiap pemimpin-gembala haruslah terbuka terhadap kritik dan masukan yang membangun. Umat juga perlu diajarkan untuk selalu belajar dan membuka diri terhadap "domba" yang berasal dari lain "kandang" sehingga proses belajar semakin terbuka. Apalagi dengan keterbukaan teknologi informasi yang semakin mengglobalkan manusia-manusia yang tidak pernah puas belajar. Inilah tantangan kita: beranikah pemimpin-gembala menjadi yang terdepan menghadapi tantangan globalisasi ini? Beranikah pemimpin-gembala merendahkan diri dan terus menjadi pelajar yang selalu memiliki semangat belajar?

\section{4) Eksploitasi dan Kerusakan Lingkungan}

Pemanfaatan sumber daya alam dan eksploitasi yang terus menerus terhadap alam tidak dapat dipungkiri telah menyebabkan menurunnya kualitas lingkungan hidup. Berbagai kerusakan lingkungan seperti degradasi lahan atau tanah, penggundulan hutan, peracunan alam di tingkat global, perubahan atmosfer serta degradasi masyarakat dan budaya merupakan fakta yang sulit dipungkiri. Degradasi lingkungan juga telah mengakibatkan terjadinya perubahan iklim yang mengakibatkan berbagai persoalan lingkungan seperti perubahan pola curah hujan yang mengakibatkan banjir dan longsor ataupun musim kemarau yang berkepanjangan. Hal ini berdampak pula terhadap pola musim tanam yang merugikan petani, karena sulit menentukan pembibitan, perkiraan hama serta serangan hama tak terduga (Nanuru, 2011).

Tantangan sumber daya alam terus terjadi dan menjadi rumit setelah desentralisasi. Misalnya, sektor kehutanan telah lama memainkan peranan yang sangat penting dalam mendukung pembangunan perekonomian dan mata pencarian masyarakat; tetapi sumber daya ini belum dikelola secara berkelanjutan atau adil. Selain itu, pertimbangan-pertimbangan lingkungan masih sangat minim di tingkat perencanaan dan penyusunan program, terutama dalam proses 
perencanaan investasi publik dan dalam rencana tata guna lahan dan sumber daya daerah (Nanuru, 2011).

Di Maluku Utara, di mana GMIH berkarya, terdapat berbagai perusahan tambang yang melanggar wilayah adat masyarakat. Kehidupan masyarakat adat tergusur dari tanahnya. Berdasarkan catatan Aliansi Masyarakat Adat Nusantara (AMAN) Maluku Utara, lebih dari 2 juta hektar lahan menjadi areal pertambangan dengan 335 izin. Dari situ, ada tiga perusahaan tambang memegang kontrak karya, yakni PT Aneka Tambang (ANTAM), PT Weda Bay dan PT Nusa Halmahera Mineral (NHM). Sisanya, izin usaha pertambangan oleh daerah. Lewat izin-izin inilah, kekayaan alam seperti emas, nikel, pasir besi, dan batubara tereksploitasi. Kita dapat belajar dari masyarakat di Gebe yang masyarakatnya bingung mau jadi apa ketika ANTAM keluar dari sana setelah sejak 1980 mengeruk kekayaan alamnya. Atau kita dapat melongok ke Pulau Ge, Halmahera Timur, yang dibabat habis ANTAM. Sekarang pulau itu "botak" dan berdampak pada berkurangnya ikan teri sehingga nelayan menjadi miskin (Doaly, 2015).

Masyarakat lingkar tambang memang selalu dijanjikan program-program pemberdayaan dan dana pengembangan masyarakat. Itu hal wajib yang diatur Undang-Undang di negara ini. Namun, jauh panggang dari api, demikianlah yang dapat dilihat pada kehidupan mereka. Jangan jauh-jauh mengarahkan pandangan ke Gebe, lihatlah masyarakat Kao dan Kao Barat. Bukankah hampir setiap saat mereka berteriak, baik lewat demonstrasi maupun lewat protes-protes di dunia maya lewat media-media sosial. Kenyataan riil ini seharusnya menjadi tantangan tersendiri bagi kepemimpinan gereja dalam menjawab masalah-masalah lingkungan di kalangan pelayanan gereja. Segerelah wahai pemimpin-gembala, jangan sampai pepatah "tikus mati dalam lumbung padi" menghantui umat atau domba gembalaan.

\section{Pemimpin Gereja: Perjuangkanlah Pluralisme dan Keutuhan Bangsa.}

Beberapa waktu lalu, bangsa Indonesia diajarkan bagaimana menyikapi suatu fenomena. Fenomena Ahok menjadikan bangsa ini sedikit "gagu" dalam menyikapi pluralisme. Masyarakat elit di ibukota sampai masyarakat pinggiran di kampung-kampung meneriakkan pendapatnya masing-masing terkait hal ini. Ahok, si Gubernur Kisten membuat bangsa ini sedikit "pusing" dalam hal menyikapi situasi politik dan hukum. Apalagi jika kacamata agama dipakai dalam melihat fenomena Ahok. Pada sisi yang lain, fenomena Islamic State of Iraq and Syria (ISIS) yang telah merambat ke Marawi, Filipina (Novi, 2017), serta gerakan terorisme Poso yang berencana memindahkan lokasi latihan mereka ke Halmahera (Ambaranie, 2017), perlu disikapi dengan gerakan cepat dan radikal dalam kepemimpinan gereja.

Konflik sosial di Maluku dan Maluku Utara tidak dapat dipungkiri masih menyisahkan dampak yang cukup menggelisahkan bagi masyarakat dan umat di Halmahera dan sekitarnya. Hal mana perlu disikapi tidak hanya dengan program-program trauma healing namun juga aksi solidaritas bersama dari kedua kelompok agama dengan bernafaskan Pancasila dan NKRI sebagai harga mati. Kepemimpinan gereja dengan demikian memerlukan dukungan program lintas denominasi dan lintas agama, serta bergandeng tangan dengan Pemerintah serta TNI dan POLRI dalam menyikapi berbagai fenomena ini.

Sebagai pemimpin-gembala, keberanian melintas-batas (passing over) diperlukan dalam kepemimpinan gereja demi menjawab tantangan pluralisme dan keutuhan bangsa. Pemimpingembala wajib hukumnya sebagai bagian dari bangsa ini untuk turut serta menjaga keutuhan bangsa. Gereja sebagai entitas bangsa dituntut untuk menjalankan fungsi sosial komunikatifnya demi memperjuangkan keamanan dan kenyamanan hidup dalam satu atap bernama Indonesia. Jangan pernah merasa rendah diri sebagai Kristen, sebagai gereja di republik ini. Gereja, sejak dulu 
selalu ikut berjuang dan terdepan dalam memperjuangkan kemerdekaan dan langkah-langkah mengisinya dengan karya lewat organisasi dan kader-kadernya.

\section{Pemimpin Gereja: Tantangan Pembinaan Kader. ${ }^{2}$}

Sebagai gereja lokal, eksistensi GMIH beberapa tahun belakangan ini (tepatnya sejak September 2013) bergelut dengan kisruh dan konflik intern yang sangat menguras pikiran elemen-elemen gerejanya (Puasa, 2014). Konflik mana telah memecah-belah institusi gereja yang berimbas pada pemecatan pendeta dari status kepegawaian, konflik memperebutkan aset di pengadilan, dan berimbas pula ke dunia pendidikan, serta perkelahian di antara jemaat yang mengakibatkan pembakaran dan pengungsian. GMIH seakan lupa bahwa kehadirannya adalah untuk memberitakan kabar kesukaan Allah, yang berdampak kedamaian bukan sebaliknya saling menyalahkan dan membiarkan jemaatnya kebingungan.

Sebagai institusi, GMIH seakan lupa bahwa jemaat-jemaat binaannya sedang terpuruk dengan persoalan ketidakadilan akibat kemiskinan, pelanggaran HAM, HIV/AIDS, tergusur dari hutan-hutan adatnya akibat konsesi tambang dan lain sebagainya. Yang saya contohkan di atas mengenai kemiskinan yang dialami jemaat di Morotai Selatan hanyalah salah satu dari sekian ratus jemaat GMIH, itupun jemaat yang masih dengan mudah dijangkau dari pusat Sinode GMIH di Tobelo. Bagaimana dengan jemaat-jemaat lain di pulau-pulau yang sulit dijangkau? Tentu suatu asumsi dapat dibangun bahwa mereka jauh lebih sengsara dari yang dikemukakan di atas. Sampai di sini, penulis dengan berani dapat menyatakan bahwa kepemimpinan gereja di GMIH selama ini telah lalai dan menelantarkan domba-dombanya karena melakukan ketidakadilan dengan membiarkan jemaatnya dalam kemiskinan. Kepemimpinan gereja di GMIH dapat dikatakan "bersalah" karena tidak berusaha membangun kerangka teologi pemberdayaan (ekonomi) guna menjawab tantangan kemiskinan dan globalisasi.

Calon-calon pemimpin gereja yang dibina di Sekolah Tinggi Teologi (STT) GMIH (sejak tahun 2008 mejadi Fakultas Teologi Universitas Halmahera) 10 tahun belakangan, menurut pengamatan penulis, cenderung dibekali untuk menjadi pengkhotbah yang etis-dogmatis. Hal ini mungkin saja terjadi karena kurikulum dan pola pendidikan teologi yang dipakai memang hanya menyiapkan sarjanasarjana teologi "mimbar" yang tugasnya berkhotbah dan berdoa. Padahal belakangan ini, pemerintah lewat Kementerian Riset, Teknologi dan Pendidikan Tinggi sedang semangatnya mensosialisasikan kurikulum pendidikan tinggi berbasis wirausaha. Mahasiswa bukan hanya diajarkan untuk pintar berteori, tetapi juga terampil dan berjiwa wirausaha. Inilah salah satu tantangan kontekstual kepemimpinan gereja di $\mathrm{GMIH}$, yaitu menjadikan tenaga-tenaga pelayannya bukan hanya pandai berkhotbah, tetapi lebih dari itu menjadikan mereka sebagai pemberdaya ekonomi jemaat lewat kemampuan manajerial yang tangguh dalam mengelola aset dan kekayaan gereja di mana ia melayani. Pemimpin-gembala bukan dilahirkan, tetapi dibuat, dikaderkan. Itulah sebabnya pola pendidikan kader haruslah dicermati dan diperbaiki setiap waktu, bukannya malah dirongrong dengan berbagai kepentingan sementara.

\footnotetext{
${ }^{2}$ Bagian ini penulis angkat dari tulisan dengan judul Gereja di Jalan Keadilan: Fungsi Sosial Gereja Menghadapi Masalah Kemiskinan dan Ketimpangan Komunikasi di Bibir Pasifik., yang merupakan sumbangan tulisan penulis pada program Simposium dan Publikasi Seri Teologi Kontekstual Tahun 2016 yang disponsori oleh Mission 21. Kumpulan tulisan tersebut sedang naik cetak tahun 2017 pada BPK Gunung Mulia.
} 
Demikianlah beberapa tantangan atau dapat dikatakan sebagai pergumulan kepemimpinan gereja, terkhusus Gereja Masehi Injili di Halmahera (GMIH) yang mestinya dijadikan pegangan dalam menjalankan proses kepemimpinan gereja. Beberapa tantangan lain semisal persoalan hak asasi manusia (HAM), masalah gender, kemitraan gereja dan pemerintah, hubungan dengan denominasi dan agama lain, dan lain sebagainya semoga tidak lepas dari perhatian kepemimpinan gereja juga.

Meghadapi tantangan tentu saja memerlukan strategi penanganan. Kepemimpinan gereja yang efektif akan memanfaatkan semua elemen sumber daya organisasi demi kemajuan dan kesejahteraan umat (Pearse, 2011). Inilah peran penting kepemimpinan gereja, yaitu menggerakkan dan memanfaatkan setiap sumber daya yang ada, bahkan sumber daya di luar gereja demi kemajuan bersama. Di sinilah kecerdasan relasional kepemimpinan gereja diuji, apakah mumpuni ataukah abal-abal. Harapannya, kepemimpinan gereja yang didalamnya ada pemimpin-gembala memiliki kecerdasan emosional, kecerdasan relasioal, dan ditunjang dengan keyakinan iman spiritual yang tangguh.

\section{Penutup}

Tulisan ini terus terang dibuat dengan terburu-buru sehingga beberapa hal mungkin saja tidak dijelaskan atau dikaji secara panjang lebar. Harapannya, pembaca dapat menelusuri dan terus belajar mencari. Bukankah dunia sekarang ada di genggaman tangan? Tidak ada informasi mengenai kepemimpinan gereja yang tersembunyi. Ratusan juta artikel kepemimpinan gereja tersebar di dunia maya, mari mempelajarinya dan menjadi bijak.

Satu hal yang perlu ditanamkan sejak dini dalam kepemimpinan gereja, yaitu bahwa pemimpingembala bukanlah Tuhan. Mereka hanyalah alat di tangan Tuhan, karena itu tidak lepas dari berbagai kelemahan juga. Kita tidak menganut paham "pengkultusan pemimpin gereja" karena itu, jangan sekali-kali menjadikan pemimpin sebagai orang kudus yang tidak boleh dikritik atau dihujat. Bukankah "anak-anak selalu melemparkan batu ke pohon mangga yang berbuah lebat?" Setiap pemimpin-gembala akan terus belajar memperbaiki diri dan memperbaiki sistem kepemimpinan agar lebih baik ke depan, begitu pun di gereja. Tradisi-tradisi yang baik di gereja patut dijaga, dan jika sudah ketinggalan zaman dan cenderung merusak, sebaiknya dilepaskan dengan ikhlas. Kata Karl Marx, filsuf Jerman: "dalam kacamata filsafat dialektika, tidak ada yang dibangun untuk sebuah keabadian, tidak ada yang absolut dan suci." Semua yang ada di bawa langit tidaklah kekal, karena kita semua menuju kepada kekekalan itu. Menutup tulisan ini, saya mengutip perkataan Albert Einsten: creativity is contagious, pass it on (kreativitas itu menular, lalui saja)". Mari, jadilah pemimpin gereja yang kreatif. Tularkan semangat kreativitas sebagai pemimpin-gembala dalam kepemimpinan gereja kita bersama.

\section{Daftar Pustaka}

Ambaranie, N. K. M. (2017, March 24). Terduga Teroris Berencana Membuat Pusat Pelatihan di Halmahera. Kompas.com. Jakarta. Retrieved from http://nasional.kompas.com/read/2017/03/24/16154981/terduga.teroris.berencana.membuat .pusat.pelatihan.di.halmahera.

Djadi, J. (2009). Kepemimpinan Kristen yang Efektif. Jurnal Jaffray, 7(1), 16-30.

Djurubasa, A., \& Nanuru, R. F. (2015). Pemetaan dan Strategi Pemberdayaan Pengentasan Kemiskinan pada Jemaat-Jemaat Gereja Masehi Injili di Halmahera (GMIH) di Kabupaten Pulau Morotai. Tobelo, LPPM Universitas Halmahera. 
Doaly, T. (2015, March 9). Ratusan Izin Tambang di Maluku Utara Libas Wilayah Adat, Kok Bisa? Mongabay Indonesia (Situs Berita Lingkungan). Maluku Utara. Retrieved from http://www.mongabay.co.id/2015/03/09/ratusan-izin-tambang-di-maluku-utara-libas-wilayahadat-kok-bisa/

Elkington, R., Meekins, D., Breen, J. M., \& Martin, S. S. (2015). Leadership as an enabling function: Towards a new paradigm for local church leadership in the 21st century. In Die Skriflig/In Luce Verbi, 49(3), 1-14. https://doi.org/10.4102/ids.v49i3.1911

Ferry, P. (2013). Analisis Ciri Kepemimpinan Hamba serta Relevansinya pada Masa Kini Berdasarkan Injil Matius 20: 26-18. Jurnal Jaffray, 13(1), 176-198.

Franklin K. (2009). Leading in mission at a higher level: How to become a reflective practitioner in mission leadership. Evangelical Missions Quarterly, 45(4), 412-418.

Jason, L. (2009). Kepemimpinan dan Tantangan Pluralisme Sosial. Jurnal Jaffray, 7(1), 1-15.

Muliana, H. T. (2013). Tantangan Kepemimpinan Masa Kini. Majalah DIA. Retrieved from http://dia.perkantas.net/tantangan-kepemimpinan-masa-kini/

Nanuru, R. F. (2011). Fungsi Sosial Gereja Menurut Konsep Rasionalitas Komunikatif Jurgen Habermas. Universitas Gadjah Mada.

Novi, C. (2017, June 13). Militer Filipina Kesulitan Merebut Marawi dari Militan Pro-ISIS. detikNews.com. Manila. Retrieved from https://news.detik.com/internasional/d3529535/militer-filipina-kesulitan-merebut-marawi-dari-militan-pro-isis

Nurgianto, B. (2016). Jumlah Pengidap HIV di Maluku Utara Mengkhawatirkan. Tempo.co. Ternate. Retrieved from https://nasional.tempo.co/read/news/2016/09/26/058807305/jumlahpengidap-hiv-di-maluku-utara-mengkhawatirkan

Pearse, N. J. (2011). Effective strategic leadership: Balancing roles during church transitions. HTS Teologiese Studies / Theological Studies, 67(2), 1-7. https://doi.org/10.4102/hts.v67i2.980

Puasa, A. (2014). Hidup Menggereja Yang Aneh. UNIERA, 3(1), 75-94. Retrieved from http://journal.uniera.ac.id/pdf_repository/juniera66-RHDWp89xoKRLKpnObTcI00E2b.pdf

Resane, K. T. (2014). Leadership for the church: The shepherd model. HTS Teologiese Studies / Theological Studies, 70(1), 1-6. https://doi.org/10.4102/hts.v70i1.2045 